\title{
Social Activists as Altruists (And Where Titmuss Comes In): Smothering the Fire They're Trying to Kindle ${ }^{1}$
}

\author{
Laura Wharton*
}

Many socially-concerned activists bemoan the unwillingness of the underprivileged to join in their political crusades. Baffled by the latter's unwillingness to take part in efforts meant for their own benefit, the lack of coordination frustrates the activists and is often cited as an explanation for their failure to achieve improvements in socio-economic conditions. The lack of cooperation between activists and the underprivileged is not new. A number of basic contradictions in the approach of the activists often stymie their efforts. Among these are altruism professed but not encouraged, dismissal of others' initiatives and conflicting views of material motivation. [Article copies available for a fee from The Transformative Studies Institute. E-mail address: journal@transformativestudies.org Website: http://www.transformativestudies.org (02017 by The Transformative Studies Institute. All rights reserved.]

KEYWORDS: Altruism, Social Activism, Egalitarianism.

In this article I begin with a brief history of the problem of activists as altruists and then point out three pragmatic contradictions that confound the political efforts of these usually intellectual and economically secure agents. First, they present themselves as motivated by altruism but argue that the poor should be motivated by self-interest. Second, intent on

\footnotetext{
* Laura Wharton, Ph.D., is an adjunct lecturer in the Department of Political Science at the Hebrew University. She received her B.A. in the Department of Government at Harvard University, a Master's degree in Russian and Slavic Studies and a Ph.D. at Hebrew University. She wrote her doctoral thesis, "The Vicissitudes of Social Ideology: From the Workers' Party of the Land of Israel to the Israeli Labor Party, 1965-1977" with advisers Prof. Itzhak Galnoor and Prof. Shlomo Avineri. In addition to teaching, Dr. Wharton is a member of the Jerusalem City Council and chair of the opposition. Address correspondence to: Laura Wharton, The Hebrew University of Jerusalem; e-mail: laura.wharton@mail.huji.ac.il.
} 